University of Texas Rio Grande Valley

ScholarWorks @ UTRGV

Chemistry Faculty Publications and

Presentations

College of Sciences

4-1-2009

\title{
Microwave-Assisted Ruthenium Trichloride-Catalyzed Synthesis of Pyrrole Fused With Indole System in Water
}

Debasish Bandyopadhyay

The University of Texas Rio Grande Valley, debasish.bandyopadhyay@utrgv.edu

Antara Banik

Sahil Bhatta

Bimal K. Banik

Follow this and additional works at: https://scholarworks.utrgv.edu/chem_fac

Part of the Chemistry Commons

\section{Recommended Citation}

Bandyopadhyay, D., Banik, A., Bhatta, S., \& Banik, B. K. (2009). Microwave-Assisted Ruthenium TrichlorideCatalyzed Synthesis Of Pyrrole Fused With Indole System In Water. Heterocyclic Communications, 15(2), 121-122. https://doi.org/10.1515/HC.2009.15.2.121

This Article is brought to you for free and open access by the College of Sciences at ScholarWorks @ UTRGV. It has been accepted for inclusion in Chemistry Faculty Publications and Presentations by an authorized administrator of ScholarWorks@ UTRGV. For more information, please contact justin.white@utrgv.edu,william.flores01@utrgv.edu. 


\author{
Debasish Bandyopadhyay, Antara Banik, Sahil Bhatta and Bimal K. Banik* \\ Department of Chemistry,, The University of Texas-Pan American, 1250 West University \\ Drive,Edinburg, Texas 78541; E-mail: banik@panam.edu
}

\author{
"Dedicated to the memory of Dr. R. R. Gupta
}

\begin{abstract}
A simple and efficient microwave-induced ruthenium trichloride-catalyzed synthesis of pyrrole fused with indole system in water is developed by reacting commercially available isatin and 4-hydroxyproline.
\end{abstract}

\title{
Introduction
}

Pyrroles important classes of compounds with many medicinal activities. ${ }^{1}$ Many methods for the synthesis of substituted pyrroles are known in the literature. ${ }^{2}$ However, synthesis of pyrroles fused to indole system has not been explored systematically. ${ }^{3}$ In a previous paper, we have described the preparation of these types of products using iodine in ethyl alcohol. ${ }^{4}$ We describe herein a new method for the synthesis of substituted pyrroles fused to indole skeleton by microwave-induced ruthenium trichloride-catalyzed reaction in water.

\section{Results and Discussion}

$\mathrm{We}^{5}$ have demonstrated bismuth nitrate-catalyzed synthesis of pyrroles following PaalKnorr method. During the course of our investigation, we have identified a ruthenium trichloride-catalyzed method for the preparation<smiles>[R]c1ccc2c(c1)C(=O)C(=O)N2[R2]</smiles>

$$
\begin{aligned}
& \text { a: } R_{1}=H, R_{2}=H \\
& \text { b: } R_{1}=H, R_{2}=C_{3} \\
& \text { c: } R_{1}=C_{3}, R_{2}=H
\end{aligned}
$$<smiles>O=C(O)C1CC(O)CN1</smiles>

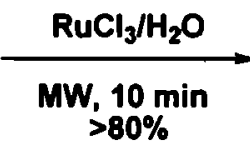
$>80 \%$<smiles>[R]c1ccc2c(c1)C(n1cccc1)C(=O)N2[R2]</smiles>

Scheme 1 
of pyrrole-substituted with indole using microwave-induced reactions in water (Scheme 1). The reaction of isatin (1) with 4-hydroxyproline (2) in water was irradiated in the presence of ruthenium trichloride $(20 \mathrm{~mol} \%)$ and water. The reaction was completed within 10 minutes. This method is therefore, unique because there are no other methods that describe the preparation of these types of heterocycles in water and within this short time. Other methods needed acidic reagents and were more time consuming. 3,4

The reaction did not proceed without ruthenium trichloride. The mechanism of the reaction is not investigated.

\section{Experimental}

To isatin ( $1 \mathrm{mmol})$, hydroxyproline $(1 \mathrm{mmol})$, ruthenium trichlorde $(20 \mathrm{~mol} \%)$ was added water $(2 \mathrm{~mL})$ and the reaction mixture was irradiated in a CEM automated microwave oven for $10 \mathrm{~min}$ (Power 300 watts and temperature $50^{\circ} \mathrm{C}$ ). The reaction was diluted extracted with dichloromethane and dried $\left(\mathrm{Na}_{2} \mathrm{SO}_{4}\right)$. Pure product (approximately, $80 \%$ ) was isolated through column chromatography (ethyl acetate/hexane $=30 / 70){ }^{6}$

\section{Conclusion}

In conclusion, we have demonstrated synthesis of pyrrole substituted indoles using ruthenium trichloride-catalyzed microwave-induced reaction under environmentally benign conditions.

\section{Acknowledgment}

We gratefully acknowledge the financial support for this research project from National Institutes of Health -SCORE (2SO6GM008038-37).

\section{References and notes}

(1) For some biologically active pyrroles. See: (a) J. A. H. Lainton, J. W. Hoffman, B. R. Martin, D. R. Compton, Tetrahedron Lett., 36, 1401, (1995); (b) C. Y. De Leon, B. Ganem, Tetrahedron, 53, 7731, (1997).

(2) (a) T. L. Gilchrist, J. Chem. Soc. Perkin Trans 1, 615, (1998). (b) R. K. Dieter, H. Yu, Org. Lett., 2, 2283, (2000). (c) N. Iwasawa, K. Maeyama, M. Saitou, J. Am. Chem. Soc., 119, 1486, (1997).

(3) J. Azizian, A. R. Karimi, Z. Kazemizadeh, A. A. Mohammadi, M. R. Mohammadizadeh, J. Org. Chem., 70, 1471, (2005).

(4) B. K. Banik, I. Garcia, F. Morales, C. Aguilar Heterocyclic Commun., 13, 109, (2007).

(5) B. K. Banik, S. Samajdar, I. Banik, J Org. Chem., 69, 213, (2004).

(6) The compounds $3 \mathrm{a}, 3 \mathrm{~b}$ and $3 \mathrm{c}$ were found to be identical in all aspects as reported in reference 4 .

Received on March 8, 2009 